\title{
Alternative potassium source for the cultivation of ornamental sunflower
}

\author{
Fonte alternativa de potássio no cultivo do girassol ornamental
}

\author{
Sabrina Thereza dos Santos Torqueti ${ }^{*}$, Karina Volpi Furtini Boldrin ${ }^{2}$, Ângela Maria Pereira do Nascimento², \\ Patrícia Duarte de Oliveira Paiva², Antônio Eduardo Furtini Neto³ , Iracema Clara Alves Luz²
}

\author{
${ }^{1}$ Universidade Federal de Lavras/UFLA, Departamento de Ciência do Solo/DCS, Lavras, MG, Brasil \\ 2Universidade Federal de Lavras/UFLA, Departamento de Agricultura/DAG, Lavras, MG, Brasil \\ ${ }^{3}$ Instituto Tecnológico Vale, Belém, PA, Brasil \\ *Corresponding author: satorqueti@hotmail.com \\ Received in october 6, 2015 and approved in january 27, 2016
}

\begin{abstract}
Brazil is dependent on importation of fertilizers, especially the potassics. Rocks and minerals that contain nutrients have a potential for use in agriculture as fertilizer, especially those of slow solubilization and that exhibit residual effect. In this context, the objective was to assess the feasibility of glauconite rock as potassium source for the cultivation of ornamental sunflower. The experiment was conducted under controlled conditions arranged in an entirely randomized design, in a $4 \times 4+4$ factorial scheme, with four replicates and one plant per plot. Four glauconite-based fertilizers were used as a potassium source: fine grained glauconite, fine grained organo-mineral glauconite, coarse grained glauconite and coarse grained organo-mineral glauconite, in four doses, as well as an additional treatment with four doses of $\mathrm{KCl}$, the principal conventional source of the nutrient. The height of the flower stalks, the diameter of the stem and floral capitulum, the number of cultivation days and post-harvest durability were evaluated. The application of $\mathrm{KCl}$ yielded the production of flower stems with greater height and larger capitulum diameter in relation to the supply of glauconite. Among the glauconite based fertilizers, the fine grained organo-mineral product provided the best flower charateristics. The postharvest commercial durability of the flower stalks was higher in plants that received the glauconite and fine grained organo-mineral glauconite. The fine grained organo-mineral glauconite surpasses all other alternative sources of potassium in relation to the agronomic characteristics evaluated.
\end{abstract}

Index terms: Helianthus annuus; glauconite; mineral nutrition; ornamental plant; postharvest.

\begin{abstract}
RESUMO
O Brasil é dependente da importação de fertilizantes, especialmente os potássicos. Rochas e minerais que apresentem nutrientes têm potencial de utilização na agricultura como fertilizante, especialmente aqueles de solubilização lenta e que apresentem efeito residual. Neste contexto, objetivou-se avaliar a viabilidade da rocha glauconita como fonte de potássio para cultivo do girassol ornamental. 0 experimento foi instalado em condições controladas arranjado em delineamento inteiramente casualizado, em esquema fatorial $4 \times 4+4$, com quatro repetições e uma planta por parcela. Utilizaram-se quatro fertilizantes à base de glauconita como fonte de potássio: glauconita farelada fina, glauconita farelada fina organomineral, glauconita farelada grossa e glauconita farelada grossa organomineral, em quatro doses, além de um tratamento adicional com quatro doses de $\mathrm{KCl}$, principal fonte convencional do nutriente. Avaliou-se a altura das hastes florais, diâmetro da haste e do capítulo floral, número de dias de cultivo e durabilidade pós-colheita. A aplicação de KCl proporcionou a produção de hastes florais com altura superior e maior diâmetro do capítulo floral em relação ao fornecimento da glauconita. Dentre os fertilizantes à base de glauconita, o produto farelado fino organomineral proporcionou melhores características das flores. A durabilidade comercial das hastes florais na pós-colheita foi maior nas plantas que receberam a glauconita e a glauconita farelada fina organomineral. A glauconita farelada fina organomineral supera as demais fontes alternativas de potássio em relação às características agronômicas avaliadas.
\end{abstract}

Termos para indexação: Helianthus annuus; glauconita; nutrição mineral; planta ornamental; pós-colheita.

\section{INTRODUCTION}

The consumption of flowers and ornamental plants worldwide has been increasing over the years (Landgraf; Paiva, 2009), a fact that has also been observed in Brazil (Junqueira; Peetz, 2014). As a result of this growth, different species have emerged in the market, providing new options for producers and consumers of flowers. From among these, the sunflower stands out, a crop used for grain production, and that is also being widely cultivated for the production of cut and potted flowers (Rodrigues et al., 2012).

The development of sunflower varieties with short stature and varying colors has allowed this plant to be represented often in arrangements and decorations. The exotic shape and intense, yellow-orange tone of its flowers 
add life and dynamism to environments (Andrade et al., 2012) as well as the possibility of its use at official events due to its similarity to the colors of the Brazilian flag.

The production of the flowers, principally cut flowers, is a high-risk activity due to the fragility of the product. The longevity of the flowers is determined by several factors pre and postharvest and is associated with genetic and anatomical characteristics of each species and their cultivars (Nowak; Rudnicki, 1990). Among the preharvest factors, adequate fertilization of plants stands out.

Potassium (K) is the second most absorbed element by the majority of crops, acting to increase the resistance of plants against drought, diseases, and lodging. It is also active in the regulation of osmotic pressure and translocation of photosynthate elements in the plant (Câmara, 2003). Potassium is the nutrient absorbed in the highest quantity in the sunflower crop (Zobiole et al., 2010). The root system of this species explores a large volume of soil, which is highly desirable, since potassium and phosphorus move in the soil preferably through diffusion (Castro et al., 2006).

Brazil is highly dependent on imported fertilizer, especially potassium, being the fourth largest consumer of fertilizers and the third largest importer of potassium (Melamed; Gaspar; Miekeley, 2009). Accordingly, rocks or minerals which have high potassium content may be potential alternative sources for producing potassium salts and / or potassium thermophosphates, or even directly applied to the soil as a slow solubilization potassium fertilizer (Nascimento; Lapido-Loureiro, 2009).

In this context, the objective was to evaluate the effect of the application of glauconite as an alternative source of potassium for the cut ornamental sunflower crop.

\section{MATERIAL AND METHODS}

The seedlings used in the experiment were obtained from the commercial ornamental sunflower seed (Helianthus annuus L. cultivar Pollenless Sunbrigth Supreme) supplied by SAKATA ${ }^{\circledR}$. The seeds were planted in trays containing the commercial substrate Tropostrato ${ }^{\circledR}$, to stimulate budding and the formation of seedlings. Two weeks after sowing, the seedlings were transplanted individually into closed pots with a 2.5 liter capacity, containing soil classified as typical Distroferric Red Latosol. The soil analysis was conducted and subsequently liming with dolomite lime was carried out aiming to reach $55 \%$ base saturation (Ribeiro; Guimarães; Alvarez, 1999).
The evapotranspired water was replenished daily with deionized water in order to achieve $60 \%$ of the total pore volume (VTP).

The base fertilization was performed according to the recommendation of Malavolta (1980) for pots, modified, which consists of applying 300,300 , and $50 \mathrm{mg} \mathrm{dm}^{-3}$ of N, P and $\mathrm{S}$, respectively, $5 \mathrm{mg} \mathrm{dm}^{-3} \mathrm{Zn}, 0.1 \mathrm{mg} \mathrm{dm}^{-3} \mathrm{Mo}, 3.6 \mathrm{mg}$ $\mathrm{dm}^{-3} \mathrm{Mn}, 5 \mathrm{mg} \mathrm{dm}^{-3} \mathrm{Fe}, 1.5 \mathrm{mg} \mathrm{dm}^{-3} \mathrm{Cu}, 0.5 \mathrm{mg} \mathrm{dm}^{-3}$ of B. The central dose of potassium fertilizer had as a reference the dose of $150 \mathrm{mg} \mathrm{dm}^{-3}$ (Malavolta, 1980).

Calcined glauconite was used as an alternative potassium source. The treatments were arranged in a $4 \times 4$ +4 factorial scheme with four sources of potassium (fine grained mineral glauconite, fine grained organo-mineral glauconite, coarse grained mineral glauconite and coarse grained organo-mineral glauconite) and four doses of glauconite in relation to the potassium dose as proposed by Malavolta (1980), equivalent to $150 \mathrm{mg} \mathrm{dm}^{3}(0 \%, 50 \%$, $100 \%$ and $200 \%$ ), as well as four additional treatments, which consisted of the application of $0,75,150$ and $300 \mathrm{mg}$ $\mathrm{dm}^{-3}$ potassium via $\mathrm{KCl}$, combined or not combined with laying chicken manure. Four repetitions were used, with one plant per plot, each pot being an experimental plot.

To define the amount of potassium, independent of the granulometry of the material used (60 or 100 mesh), calculations were made based on the total content of calcined glauconite, equivalent to $7.52 \% \mathrm{~K}_{2} \mathrm{O}$ (Methodology $4 \mathrm{~A}-4 \mathrm{~B}$ ACME Analytical Laboratories) (Table 1).

Table 1: Concentrations of the nutrients in the potassium source.

\begin{tabular}{cc}
\hline Nutrients & Concentration (\%) ${ }^{*}$ \\
\hline $\mathrm{Al}_{2} \mathrm{O}_{3}$ & 10.53 \\
$\mathrm{SiO}_{2}$ & 41.83 \\
$\mathrm{TiO}_{2}$ & 0.53 \\
$\mathrm{MnO}$ & 0.10 \\
$\mathrm{Fe}_{2} \mathrm{O}_{3}$ & 4.75 \\
$\mathrm{Cr}_{2} \mathrm{O}_{3}$ & $<0.01$ \\
$\mathrm{CaO}$ & 31.94 \\
$\mathrm{MgO}$ & 2.45 \\
$\mathrm{P}_{2} \mathrm{O}_{5}$ & 0.17 \\
$\mathrm{Na}_{2} \mathrm{O}$ & 0.19 \\
$\mathrm{~K}_{2} \mathrm{O}$ & 7.52 \\
$\mathrm{SO}_{3}$ & $<0.01$ \\
\hline
\end{tabular}

* Analytical Method /Laboratory: ACME Analytical Laboratory (ISO 9002 Accredited Co.). 
Agronomic evaluations of the plants were conducted observing the characteristics of the shoots after the emission of the floral bud and the characteristics of the inflorescences: the height of flower stem, diameter of the flower stem and diameter of the capitulum.

To evaluate the postharvest durability, the inflorescences were collected with the capitulum partially open. The flower stalks were kept in cold storage until their disposal, at a temperature of $12{ }^{\circ} \mathrm{C}$ and assessed by two evaluators as to the quality, every two days.

The evaluation of quality was performed in accordance with the senescence scale established by Curti, et al. (2012), being Score 5: excellent general aspect, flowers with a glow and fully opened, a turgid capitulum, injury free, and a very attractive appearance; Score 4: good general aspect, open flowers with a glow, gentle inclination of the flower stem, with a turgid capitulum, absence of injuries, stains and wrinkling of the ray flowers; Score 3: early stage of deterioration of the capitulum, slightly opaque color, visible stamens, ligulate flowers upside down or inside the capitulum. At this stage, the limit of the acceptance of the flower is found, depreciating the commercial value; Score 2: very evident signs of wilting, curling of flowers inside and / or outside of the disc, dull ligulate flowers and stems that bend downwards; Score 1: totally withered ligulate ray flowers and disc flowers (center of the capitulum) fully open and with intense formation of pollen (undesirable in ornamentation), the stems are warped and begin to deteriorate; Score 0: ligulate flowers of the ray and of the disc are totally open and wilted, complete senescence of the capitulum and the ligulate ray flowers, and pronounced darkening of the petals.

The data obtained in the experiment were pooled and subjected to a variance analysis and test $\mathrm{F}$. When significant $(\mathrm{P}<0.05)$, the average quantitative data were submitted to regression testing and the qualitative data was submitted to the Scott-Knott test at 5\% probability, with the help of the statistical software SISVAR (Ferreira, 2014). Furthermore, the data for post-harvest durability underwent orthogonal contrasts with the aid of the same software.

\section{RESULTS AND DISCUSSION}

The flower stalk height of the ornamental sunflower was influenced by the sources and doses of potassium in isolation. Plants grown with a potassium source of a smaller grain size with the addition of manure obtained an average height of $46.8 \mathrm{~cm}$, superior to all other potassium sources used (Figure 1). Andrade et al. (2012) cultivating four ornamental sunflower genotypes for cutting, irrigated with wastewater and with water from the water supply in an organic production system observed an average plant height of $57.55 \mathrm{~cm}$ when irrigated with water from the water supply and $71.18 \mathrm{~cm}$ when irrigated with wastewater. This difference in height could be related to genotypic differences among cultivars and also the irrigation water composition, especially in relation to the nitrogen, phosphorus and potassium present in the wastewater.

The superiority of the ornamental sunflower plants cultivated with fine grained organo-mineral glauconite could be related as much to the smaller particle size of the rock as to the addition of laying hen manure. The release of organic acids during the decomposition of laying hen manure certainly allowed greater solubilization of glauconite, promoting a greater release of potassium for ornamental sunflower. Added to this, the smaller particle size of the material could have facilitated the nutrient solubilization process of the glauconite.

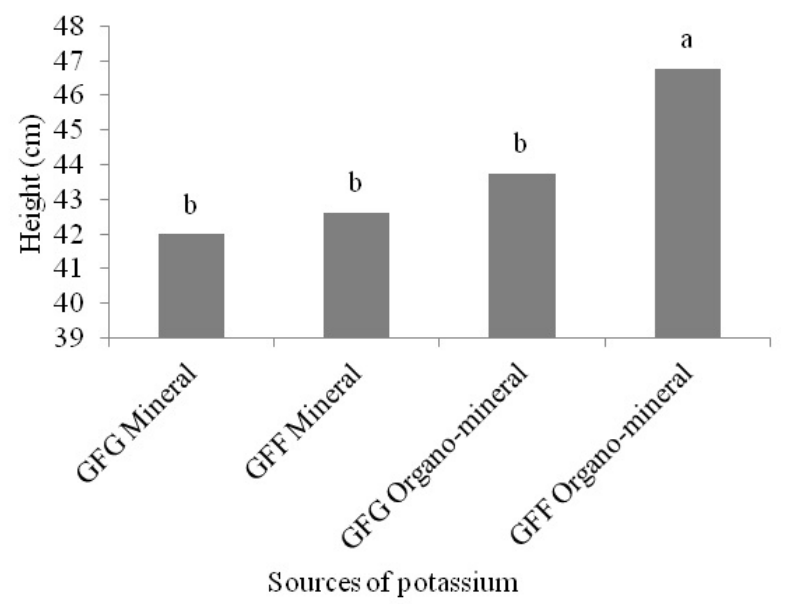

Figure 1: Height of the flower stalks of ornamental sunflower plants grown with different alternative sources of potassium: GFG (Coarse Grained Glauconite) Mineral, GFF (Fine Grained Glauconite) Mineral, GFG (Coarse Grained Glauconite) organo-mineral, GFF (Fine Grained Glauconite) organo-mineral. Averages followed by same letter do not differ amongst themselves according to the Scott-Knott test at 5\% probability.

The flower stalks formed by sunflower plants grown with conventional glauconite and a conventional potassium source presented a height of $43.78 \mathrm{~cm}$ and 53.71 $\mathrm{cm}$ respectively, representing a difference of $10 \mathrm{~cm}$ on average. The higher the flower stem the higher the final price of the species for commercialization. 
The doses of potassium influenced the height of the ornamental sunflower flower stalks independent of the potassium source used. The estimated potassium dose of $264.25 \mathrm{mg} \mathrm{dm}^{-3}$ afforded the maximum height of the buds (Figure 2), from plants that received glauconite as potassium source.

Only potassium doses influenced the diameter of the flower stalks of the ornamental sunflower, the maximum diameter being obtained with an application of $197.83 \mathrm{mg} \mathrm{dm}^{-3}$ potassium (Figure 3). The application of $\mathrm{KCl}$ provided the largest diameter flower stalks when compared with the alternative sources of potassium, on average, $9.24 \mathrm{~mm}$ and $7.38 \mathrm{~mm}$, respectively.

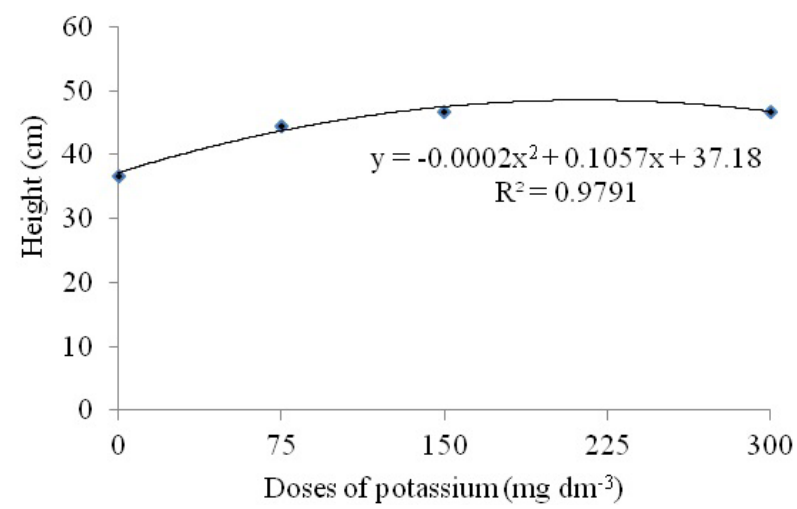

Figure 2: Height of the flower stalks of ornamental sunflower plants grown with different alternative doses of potassium.

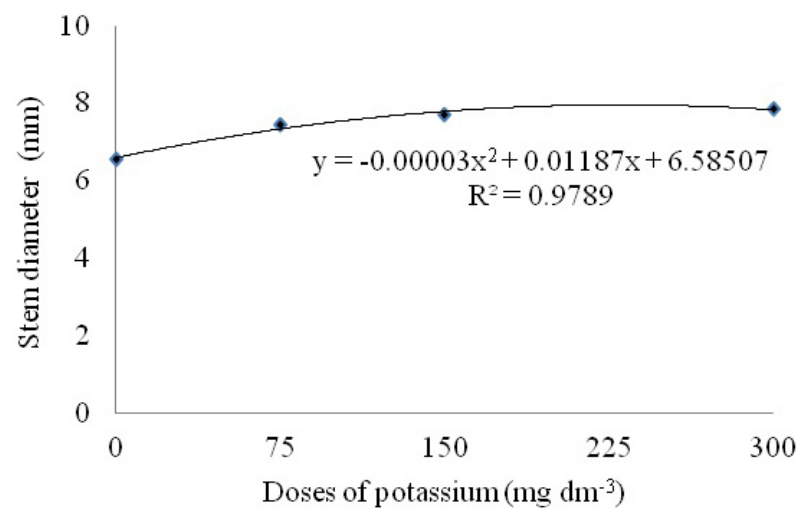

Figure 3: Stem diameter of the flower stalks of ornamental sunflower plants grown with different doses of potassium.

Neves et al. (2005) by growing ornamental sunflower in soil and hydroponically, it was observed that the plants had a maximum stem diameter of 13.0 $\mathrm{mm}$ when cultivated with gravel and quartz and $8.0 \mathrm{~mm}$ when cultivated in soil. In this case, it could be inferred that plants grown with both $\mathrm{KCl}$ and alternative sources of potassium presented a stem diameter consistent with other reports in literature. Larger diameter stems are more rigid, which reduces the likelihood of damage to the flowers at harvest and postharvest (Nowak; Rudnicki, 1990), as well as facilitating transport and commercialization.

The diameter of the capitulum of ornamental sunflower plants was influenced by the doses and sources of potassium. The plants grown with a conventional source exhibited a larger capitulum diameter in relation to those plants cultivated with alternative sources of potassium, with averages of 12.2 and $10.0 \mathrm{~cm}$, respectively (Figure 4). The diameter of the inflorescence and plant height, are the variables that indicate the commercial value of the ornamental sunflower plant (Neves et al., 2005). The larger the diameter of the inflorescence, the greater the value of the stem in the market. Moreover, larger inflorescences are associated with better visual quality, an essential characteristic for the composition of floral arrangements. Based on these attributes, potassium supply via $\mathrm{KCl}$ provided greater commercial value to the ornamental sunflower.

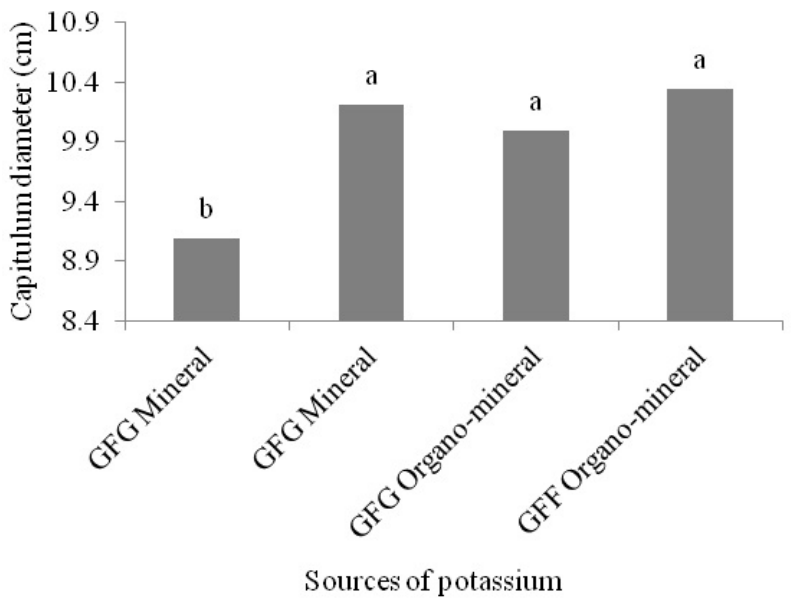

Figure 4: Capitulum diameter of the flower stalks of ornamental sunflower plants grown with different alternative sources of potassium: GFG (Coarse Grained Glauconite) Mineral, GFF (Fine Grained Glauconite) Mineral, GFG (Coarse Grained Glauconite) organomineral, GFF (Fine Grained Glauconite) organomineral. Averages followed by same letter do not differ amongst themselves according to the Scott-Knott test at $5 \%$ probability. 
Among the alternative sources of potassium, those with smaller granulometry, with or without the addition of laying hen manure, and the coarse grained organomineral glauconite, provided a larger diameter capitulum in the ornamental sunflower (Figure 4) with a average diameter of $10.34,10.21$ and $10.0 \mathrm{~cm}$, respectively. These inflorescences presented suitable characteristics for the commercialization of ornamental sunflower as a cut flower, with a diameter of inflorescences above $10.0 \mathrm{~cm}$ on average from bract to bract (Sakata Seed Corporation, 2003). The coarse grained mineral glauconite provided smaller diameter ornamental sunflower flowers compared to other sources used, with inflorescences measuring on average $9.0 \mathrm{~cm}$ in diameter.

The diameter of the ornamental sunflower plant capitulum was influenced by different doses of potassium. The estimated dose of $194.62 \mathrm{mg} \cdot \mathrm{dm}^{-3}$ was that which provided the maximum diameter of the capitulum of the plants (Figure 5). This estimated dose is very similar to the dose that provided the maximum diameter of the flower stalks ( $\left.197.83 \mathrm{mg} \mathrm{dm}^{-3}\right)$, suggesting that potassium levels around $200 \mathrm{mg} \mathrm{dm}^{-3}$ are adequate for the adequate development and production of ornamental sunflower as a cut flower.

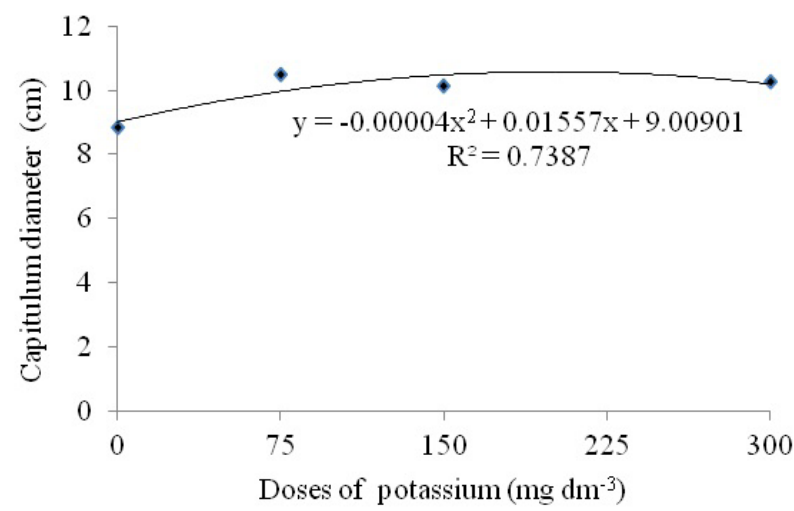

Figure 5: Capitulum diameter of the flower stalks of ornamental sunflower plants grown with different doses of potassium.

The ornamental sunflower plants showed a cultivation cycle of 31 to 35 days, less than the average of 50 to 60 days suggested by the company supplying the seed for this cultivar. This early yield may be related to the experimental cultivation environment, developed in the greenhouse during months of high temperatures (October and November), with maximums of $30.7^{\circ} \mathrm{C}$ and $27.8^{\circ} \mathrm{C}$ respectively (ECP-INMET/UFLA). Despite reports that high temperatures and low relative air humidity can accelerate the sunflower bloom, impeding pollination, killing the apical bud and causing anomalies (Castro; Farias, 2005), no abnormal symptoms were observed in the plants during the trail period.

The number of cultivation days was influenced by the sources and doses of potassium, being that those plants grown with coarse grained mineral glauconite and fine grained organo-mineral glauconite were harvested in advance in relation to the other plants (Figure 6). Comparing the alternative sources with $\mathrm{KCl}$, the latter promoted fewer cultivation days. With the increase of $\mathrm{KCl}$ doses applied, there was a reduction in the number of days to harvest (Figure 7), suggesting a tendency towards a reduction of the crop cycle when higher potassium doses are applied. These results corroborate in part with Fagundes et al. (2007), who observed earlier opening flowers as a result of higher nitrogen supplementation, also suggesting the effect of potassium on the precocity of the species.

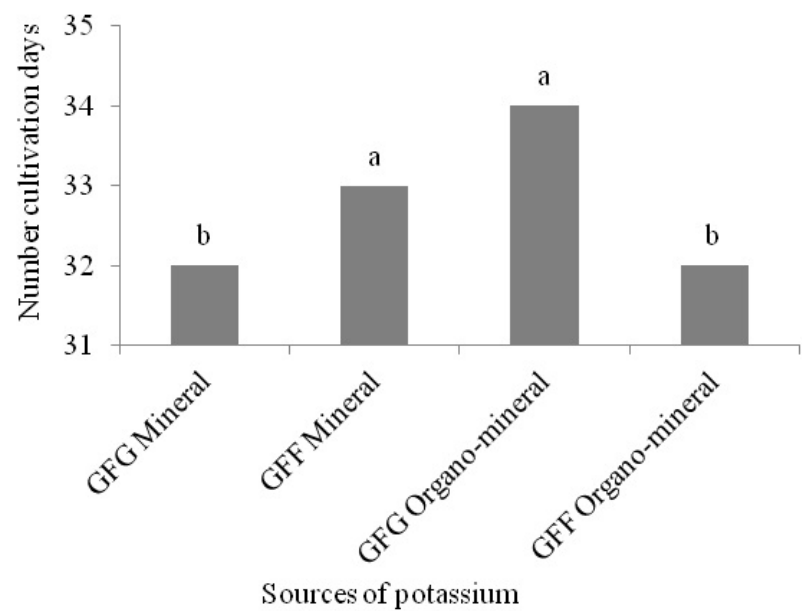

Figure 6: Number of cultivation days of the flower stalks of ornamental sunflower plants grown with different alternative sources of potassium: GFG (Coarse Grained Glauconite) Mineral, GFF (Fine Grained Glauconite) Mineral, GFG (Coarse Grained Glauconite) organo-mineral, GFF (Fine Grained Glauconite) organomineral. Averages followed by same letter do not differ amongst themselves according to the Scott-Knott test at $5 \%$ probability.

The overall durability of ornamental sunflower flower stems post-harvest was greater in the plants that received potassium fertilization, independent of the use 
of glauconite or potassium chloride as a nutrient source, which can be attributed to the essentiality of potassium for the growth and production of the plant. Potassium is the nutrient responsible for the control of turgidity of the tissue, activation of the many enzymes involved in respiration and photosynthesis, opening and closing of the stomata, transport of carbohydrates, transpiration, resistance to frost, drought, salinity, and to disease, resistance to lodging and the maintenance of the quality of the product (Marschner, 2012). Potassium is necessary in large quantities for the plant and can be applied through chemical or organic fertilization, such as glauconite associated with organic material (Ashkevari; Hossein Zadeh; Miransari, 2010). The application of $300 \mathrm{mg} \mathrm{dm}^{-3}$ potassium via organo-mineral glauconite surpassed the application of potassium via $\mathrm{KCI}$ in relation to overall durability. The greater durability of the flower stems cultivated with glauconite in relation to fertilization with $\mathrm{KCI}$ could be related to the composition of the rock, composed of approximately, $40 \% \mathrm{SiO}_{2}$ (Table 1). Silicon isn't an element considered essential for the plants, despite promoting beneficial effects in determined species, such as a higher resistance and tolerance to biotic and abiotic factors (Epstein, 1999), greater growth, quality and durability postharvest. Generally, the substrates utilized for the cultivation of ornamental flowers and plants, much like commercial fertilizers, contain a low concentration of silicon (Chen et al., 2000; Epstein, 1994), and are frequently the only source of the element is irrigation water. Glauconite, a silicate rock, could be interesting for the cultivation of horticultural species, especially those that have a good capacity to accumulate the element. In general, dicots tend to accumulate less silicon than monocots, although the ornamental sunflower could be considered and accumulator species of the element, principally in the leaves, flowers and flower stalks (Kamenidou; Cavins; Marek, 2008). Silicon could reduce the rate of transpiration of the flower stalks, which provided greater durability postharvest. The decrease in the rate of transpiration is associated with a possible accumulation of silicon in the cell wall, and a dual polymerized layer deposited in the cuticle, which presumably could reduce transpiration (Ma; Takahashi, 2002).

The commercial durability of the ornamental sunflower was higher in plant stems from plants that received potassium via mineral glauconite and fine grained organo-mineral glauconite, with an average commercial durability of 20 and 18 days, respectively. The floral industry standard for post-harvest flower durability is 10 days (Gast, 1995), suggesting that the ornamental sunflower stems cultivated with glauconite surpass the acceptable commercial durability for cut flowers. The flower stalks receiving potassium nutrition via coarse grained organo-mineral glauconite remained commercially acceptable for 16 days on average, this durability inferior in relation to the other sources used, and superior to the standard of durability established for the species.

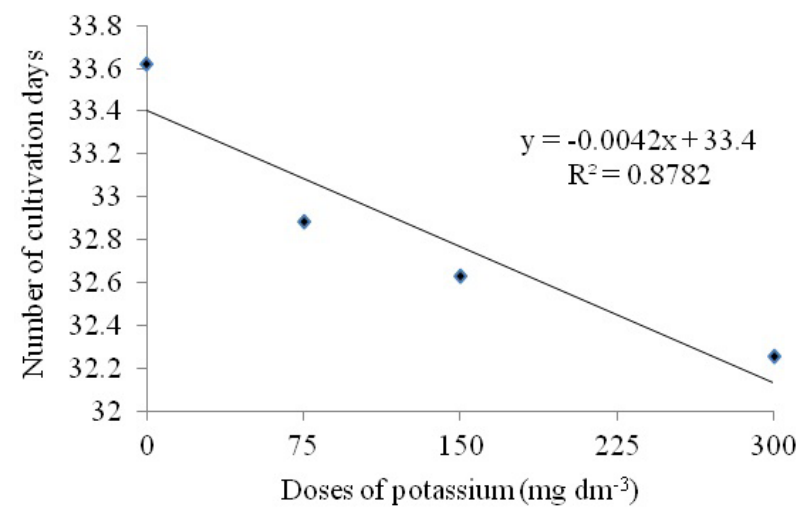

Figure 7: Number of cultivation days of the flower stalks of ornamental sunflower plants grown with different doses of potassium.

The low concentration and solubility of nutrients in rocks and minerals can limit the use of alternative sources to meet the demand required by the Floriculture Agribusiness. Accordingly, to reduce the use of conventional fertilizers and consequently reduce international dependence, glauconite with fine granulometry and in the form of an organo-mineral fertilizer could be an alternative in the production and postharvest durability of the ornamental sunflower. Despite the superiority of the conventional source in the development of flower stalks, the final quality of ornamental sunflower cultivated with alternative sources of potassium meets the quality standards and requirements of the consumer market. Moreover, by presenting a slower solubility than conventional fertilizers, it constitutes a source of nutrients with residual effect, favoring a longterm action of the applied input (Melahmed; Gaspar; Miekeley, 2009). It also presents itself as a viable alternative in economic and environmental terms due to the low cost of processing, and due to the gradual release of nutrients that reduces losses through leaching.

\section{CONCLUSIONS}

The use of potassium chloride provided better agronomic characteristics in ornamental sunflower, except in post-harvest durability. Fine grained organo-mineral glauconite provided a greater stem height in ornamental 
sunflower and a higher commercial durability post-harvest, compared to other combinations of rock. Potassium doses close to $200 \mathrm{mg} \cdot \mathrm{dm}^{-3}$ are adequate for the good development and production of ornamental sunflower as a cut flower when using glauconite as a nutrient source.

\section{REFERENCES}

ANDRADE, L. O. et al. Crescimento de girassóis ornamental em sistema de produção orgânica e irrigada com água residuária tratada. Irriga, 1(1):69-82, 2012.

ANDRADE, L. O. et al. Qualidade de flores de girassóis ornamentais irrigados com águas residuária e de abastecimento. Idesia, 30(2):19-27, 2012.

ASHKEVARI, A.; HOSSEIN ZADEH S. H.; MIRANSARI M. Potassium fertilization and fruit production of page citrus on a punsirus rootstock; quantitative and qualitative traits. Journal of Plant Nutrition, 33:1564-1578, 2010.

CÂMARA, G. M. S. Girassol: Tecnologia da Produção. In: LPV 0506: Plantas Oleaginosas. Piracicaba: ESALQ, Departamento de Produção Vegetal, 2003. p.153-180.

CASTRO, C.; FARIAS, J. R. B. Ecofisiologia do Girassol. In: LEITE, R. M. V. B. C.; BRIGHENTI, A. M.; CASTRO, C. Girassol no Brasil. Londrina: Embrapa Soja, 2005. p.163-218.

CASTRO, C. et al. Rochas Brasileiras como fonte alternativa de potássio para a cultura do girassol. Espaço \& Geografia, 9(2):179-193, 2006.

CHEN, J. et al. Let's put the Si back into soil. Part I. Greenhouse Product News, 10:44-47, 2000.

CURTI, G. L. et al. Girassol ornamental: caracterização, póscolheita e escala de senescência. Revista de Ciências Agrárias, 35(1):240-250, 2012.

EPSTEIN, E. The anomaly of silicon in plant biology. Proceedings of the National Academy of Sciences, 91:11-17, 1994.

EPSTEIN, E. S. Annual Review of Plant Physiollogy and Plant Molecular Biology, 50:641-646, 1999.

FAGUNDES, J. D. et al. Crescimento, desenvolvimento e retardamento da senescência foliar em girassol de vaso (Helianthus annuus L.): fontes e doses de nitrogênio. Ciência Rural, 37(4):987-993, 2007.

FERREIRA, D. F. SISVAR: a Guide for its Bootstrap procedures in multiple comparisons. Ciência e Agrotecnologia, 38(2):109-112, 2014.
GAST, K. L. B. Production and postharvest evaluation of fresh-cut sunflowers. Report of Progres 751, Agricultural Experiment Station, Kansas State University, Manhattan, 1995.

JUNQUEIRA, A. H.; PEETZ, M. S. O setor produtivo de flores e plantas ornamentais do Brasil, no período de 2008 a 2013: atualizações, balanços e perspectivas. Revista Brasileira de Horticultura Ornamental, 20(2):115-120, 2014.

KAMENIDOU, S.; CAVINS, T. J.; MAREK, S. Silicon supplements affect horticultural traits of greenhouse-produced ornamental sunflowers. HortScience, 43:236-239, 2008.

LANDGRAF, P. R. C.; PAIVA, P. D. O. Produção de flores cortadas no estado de Minas Gerais. Ciência e Agrotecnologia, 33(1):120-126, 2009.

MA, J. F.; TAKAHASHI, E. Soil, Fertilizer, and Plant Silicon Research in Japan. Elsevier Science B.V., Amsterdam, 2002. 280p.

MALAVOLTA, E. Elementos de nutrição mineral de plantas. São Paulo: Agronômica Ceres, 1980. 251p.

MARSCHENER, $H$. Mineral nutrition of higher plants. 3.ed. London: Academic Press, 2012. 651p.

MELAMED, R.; GASPAR, J. C.; MIEKELEY, N. Pó de rocha como fertilizante alternativo para sistemas de produção sustentável. In: LOUREIRO, F. E. L.; MELAMED, R.; FIGUEIREDO NETO, J. Fertilizantes: Agroindústria e Sustentabilidade. Rio de Janeiro: CETEM/MCT, 2009. p.385-396.

NASCIMENTO, M.; LAPIDO-LOUREIRO, F. E. L. O potássio na agricultura brasileira: fontes e rotas alternativas. In: LAPIDOLOUREIRO, F. E. L.; MELAMED, R.; FIGUEIREDO NETO, J. Fertilizantes: agroindústria e sustentabilidade. Rio de Janeiro: CETEM/MCT, 2009. p.305-336

NEVES, M. B. et al. Desenvolvimento de plantas de girassol ornamental (Helianthus annuus L.) em vasos, em dois substratos com solução nutritiva e em solo. Científica, 33(2):127-133, 2005.

NOWAK, J.; RUDNICKI, R. M. Postharvest handling and storage of cut flowers, florist greens and potted plants. Portland: Timber Press, 1990. 210p.

RIBEIRO, A. C.; GUIMARÃES, P. T. G.; ALVAREZ, V. H. (Ed.). Recomendações para uso de corretivos e fertilizantes em

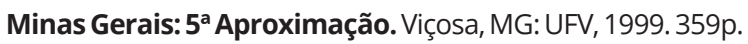

RODRIGUES, E. J. R. et al. Girassol. In: PAIVA, P. D. O.; ALMEIDA, E. F. A. Produção de Flores de Corte. Lavras: Editora UFLA, 2012, p.402-446.

Ciência e Agrotecnologia 40(3):257-264, May/Jun. 2016 
SAKATA SEED CORPORATION. Sakata's reliable seeds: flower seed catalogue 2001-2003. Bragança Paulista: Sakata Sementes Agroflora, 2003. p.99.
ZOBIOLE, L. H. S. et al. Marcha de absorção de macronutrientes na cultura do girassol. Revista Brasileira de Ciência do Solo, 34(2):425-433, 2010. 